\title{
HUBUNGAN PERSEPSI IBU RUMAH TANGGA TENTANG BANK SAMPAH DENGAN PARTISIPASI PENGELOLAAN BANK SAMPAH GAWE RUKUN, KOTA TANGERANG
}

\author{
Correlation Housewife's Perception about Waste Bank and Participation of \\ 'Gawe Rukun’ Waste Bank Management in Tangerang City \\ Eka Putri Azrai, Ernawati, Santi Rizkiani \\ Pendidikan Biologi Fakultas MIPA Universitas Negeri Jakarta \\ Corresponding author; Email: epazrai@yahoo.com
}

\begin{abstract}
Participation of waste bank management is the involvement of physical, mental, and emotional a person to participate actively, contributing, and responsible for the group's goal, in this case the waste bank management activities. One of the factor which participation of 'Gawe Rukun' Waste Bank management affect is perception. The purpose of this research was to determine the correlation between housewife's perception about waste bank and participation of 'Gawe Rukun' Waste Bank management. This research was held in RW 01, Kelurahan Kunciran Indah, Tangerang City on April to May 2016. The method used was survey method with correlational study. The sample of this research 151 housewife's were selected by using simple random sampling. The prerequisite test showed that the data was normal and homogen. Hypothesis test using linear regression test and simple correlation. Regression model obtained $\hat{Y}=92.511+0.737 \mathrm{X}$ had a significant and linear correlation. The coefficient of correlation obtained was 0.7502 , which means there was a positive relationship between housewife's perception about waste bank and participation of 'Gawe Rukun' Waste Bank management. The coefficient of determination obtained was 0.5628 , which means housewife's perception about waste bank contributed $56.28 \%$ to the participation of 'Gawe Rukun' Waste Bank management.
\end{abstract}

Keywords : Housewife's, management, participation, perception, waste bank

\section{PENDAHULUAN}

Pembangunan di perkotaan menyebabkan laju pertumbuhan ekonomi serta daya tarik yang luar biasa bagi masyarakat untuk melakukan urbanisasi. Pesatnya pembangunan yang terjadi di perkotaan menimbulkan dampak negatif yang mengganggu lingkungan perkotaan. Pertambahan penduduk yang terjadi menyebabkan kegiatan produksi dan konsumsi masyarakat meningkat yang pada akhirnya menyebabkan peningkatan volume, jenis, dan karakteristik sampah yang semakin beragam (Chalik, 2011).

Solusi untuk sistem pengelolaan sampah dengan pendekatan 3R yaitu melalui sistem bank sampah. Sistem bank sampah merupakan kegiatan social engineering yang mengajarkan masyarakat untuk memilah sampah sejak dari sumbernya (Wahyuni, 2014). Sistem bank sampah diharapkan dapat mengurangi volume sampah yang diangkut ke Tempat Pembuangan Akhir (TPA) dan meningkatkan perekonomian masyarakat. Konsep bank sampah pertama kali dicetuskan oleh Bambang Suwerda pada 
tahun 2008 melalui Bank Sampah Gemah Ripah, di Desa Badegan, Kabupaten Bantul, Provinsi Daerah Istimewa Yogyakarta (Utami, 2013).

Kota Tangerang merupakan salah satu kota yang berbatasan dengan Ibu Kota Negara, dengan luas wilayah $184,24 \mathrm{~km}^{2}$ dan jumlah penduduk 1,9 juta jiwa serta volume sampah yang dihasilkan per hari $5602 \mathrm{~m}^{3}$ atau 1400 ton (Badan Pusat Statistik Kota Tangerang, 2013). Volume sampah tersebut akan terus meningkat sejalan dengan pertambahan penduduk. Oleh karena itu, pemerintah Kota Tangerang mencanangkan program 1000 bank sampah pada tahun 2012 dan diharapkan dapat terealisasikan secara sempurna pada tahun 2015 (Ganet, 2013).

Program 1000 bank sampah yang telah dibuat oleh pemerintah ternyata masih belum dapat tercapai sesuai dengan target yang telah ditentukan. Hal ini terlihat dari sekitar 300 bank sampah yang baru terbentuk sampai dengan tahun 2014 (Dinas Kebersihan dan Pertamanan Kota Tangerang, 2015).

Salah satu bank sampah di Kota Tangerang yang menjadi contoh sekaligus pelopor dalam menjalankan sistem bank sampah adalah Bank Sampah Gawe Rukun yang terletak di RW 01 Kelurahan Kunciran Indah dan diprakarsai oleh Tukidi S.E, S. Kom, M.M sejak 30 Oktober 2011 (Ganet, 2013). Berdasarkan hasil wawancara dengan Tukidi S.E., S. Kom, M.M, Ketua RW 01, diketahui bahwa terdapat penurunan jumlah nasabah yang aktif menabung. Manfaat yang diberikan oleh bank sampah ternyata masih belum bisa membuat masyarakat tertarik menjadi nasabah bank sampah dan ikut berpartisipasi dalam pengelolaan bank sampah. Hal ini dikarenakan masih ada masyarakat yang menganggap bahwa bank sampah tidak dapat menyelesaikan permasalahan sampah yang ada.

Partisipasi masyarakat menjadi salah satu faktor dalam menyukseskan program lingkungan, seperti bank sampah. Keharusan berpartisipasi bertolak dari arah bahwa lingkungan hidup adalah milik bersama yang pemeliharaannya harus dilaksanakan oleh pemerintah, pelaku usaha, dan masyarakat (Mikkelsen, 2003).

Ibu rumah tangga merupakan bagian dari anggota masyarakat yang berperan penting dalam pengelolaan bank sampah. Hal ini dikarenakan ibu rumah tangga mengetahui tentang sampah yang dihasilkan oleh keluarganya dan lebih sering berinteraksi dengan lingkungan tempat tinggalnya. Persepsi merupakan salah satu faktor yang menentukan partisipasi dalam pengelolaan. Untuk dapat berpartisipasi dalam pengelolaan bank sampah, perlu diperhatikan persepsinya terhadap bank sampah. Individu yang berpartisipasi sebagian besar dilandasi oleh persepsi yang dimiliki (Chaesfa dan Nurmala, 2013). Persepsi yang baik dan positif menyebabkan tingginya partisipasi masyarakat. Persepsi yang buruk dan negatif menyebabkan masyarakat tidak ikut berpartisipasi sehingga akan menghambat pembangunan (Emby, et al., 2011).

Oleh karena itu, penelitian ini bertujuan untuk mengukur kekuatan hubungan antara persepsi ibu rumah tangga tentang bank sampah dengan partisipasi pengelolaan Bank Sampah Gawe Rukun di RW 01 Kelurahan Kunciran Indah, Kota Tangerang. Dengan demikian, hasil dari penelitian ini diharapkan dapat dijadikan bahan pertimbangan dan masukan kepada pemerintah dalam melakukan tindakan pemberian penyuluhan dan pelatihan yang berkaitan dengan sistem bank sampah, sehingga sistem bank sampah yang diterapkan dapat berjalan dengan baik dan berkelanjutan.

\section{METODE}

nelitian ini menggunakan metode survei dengan studi korelasional. Variabel bebas (X) 
pada penelitian ini adalah persepsi ibu rumah tangga tentang bank sampah, sedangkan variabel terikat (Y) adalah partisipasi pengelolaan Bank Sampah Gawe Rukun.

Penelitian dilaksanakan di RW 01 Kelurahan Kunciran Indah, Kota Tangerang, pada bulan April-Mei 2016. Sampel yang digunakan pada penelitian ini adalah $151 \mathrm{ibu}$ rumah tangga yang ditentukan dengan cara simple random sampling.

\section{HASIL PENELITIAN}

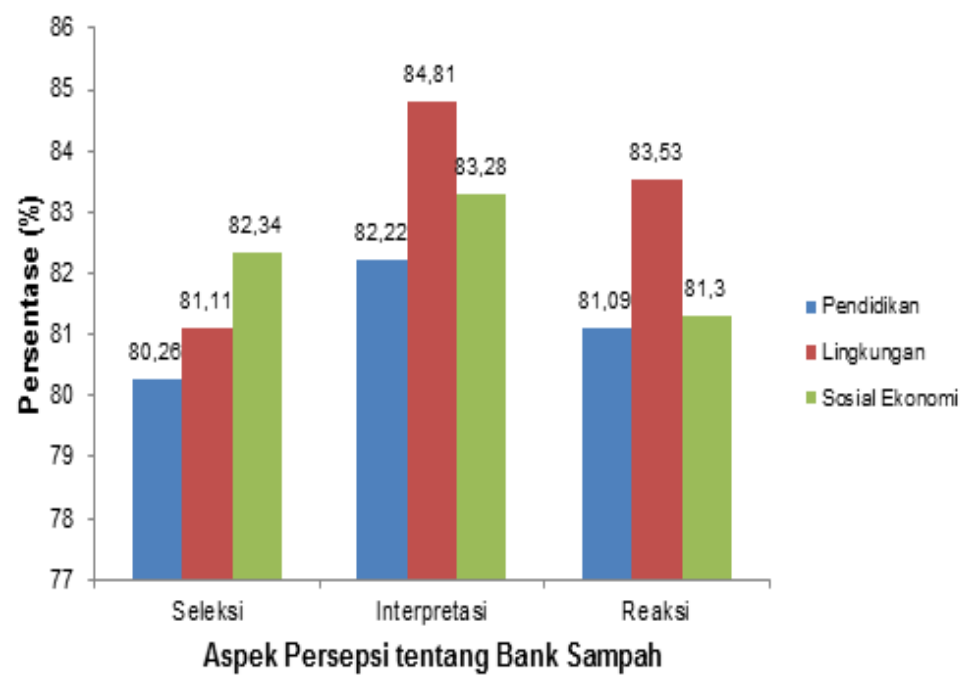

Gambar 1. Pengkategorian Skor Persepsi Ibu Rumah Tangga tentang Bank Sampah

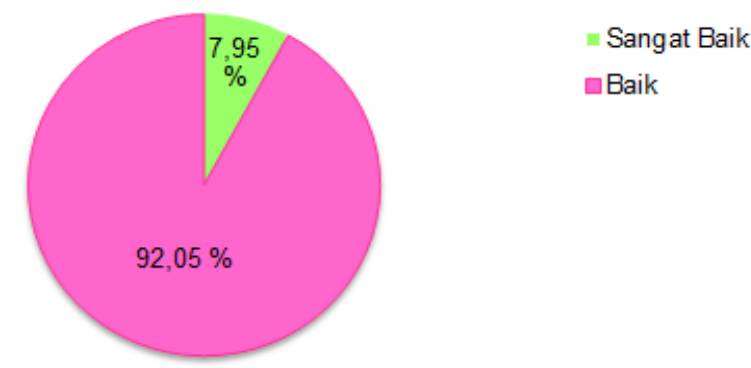

Gambar 2. Perbandingan Persentase Setiap Aspek pada Persepsi Ibu Rumah Tangga tentang Bank Sampah

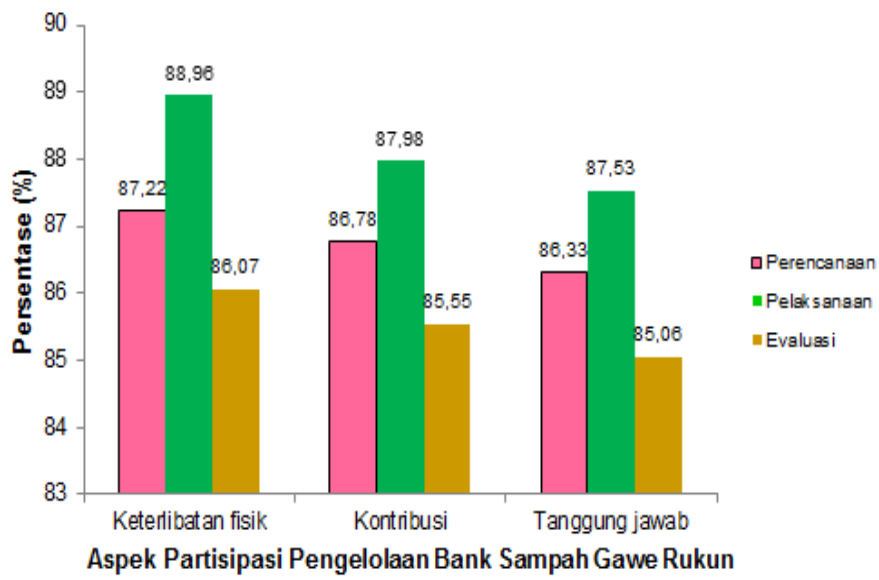


Gambar 3. Pengkategorian Skor Partisipasi Pengelolaan Bank Sampah Gawe Rukun

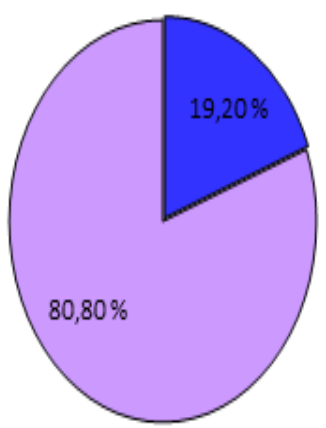

QSangat Tinggi

口Tinggi

Gambar 4. Perbandingan Persentase Setiap Aspek pada Partisipasi Pengelolaan Bank Sampah Gawe Rukun

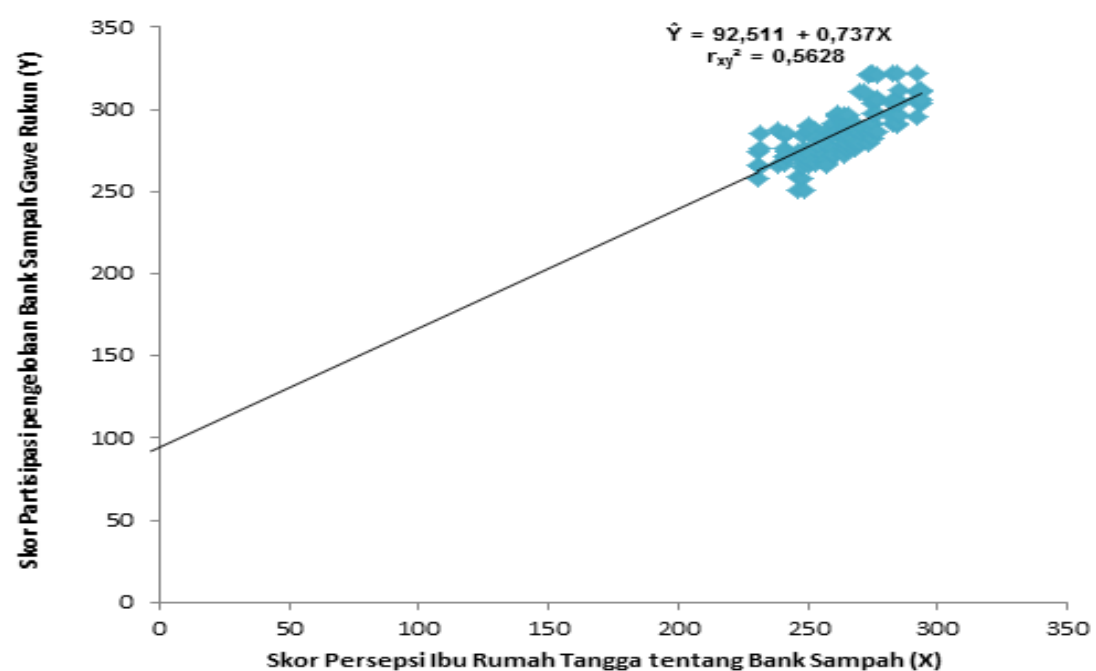

Gambar 5. Model Regresi Linier antara Persepsi dengan Partisipasi

\section{PEMBAHASAN}

Berdasarkan hasil analisis dapat diketahui bahwa terdapat hubungan positif antara persepsi ibu rumah tangga tentang bank sampah dengan partisipasi pengelolaan Bank Sampah Gawe Rukun. Artinya, semakin baik persepsi ibu rumah tangga tentang bank sampah maka partisipasi pengelolaan Bank Sampah Gawe Rukun semakin tinggi. Hal ini sesuai dengan pernyataan bahwa persepsi masyarakat yang baik akan mendorong tingginya partisipasi masyarakat (Purwanti et al., 2014).

Koefisien korelasi dari hasil penelitian menunjukkan hubungan yang kuat antara persepsi dengan partisipasi. Hal ini didukung oleh Chaesfa dan Nurmala (2013) dimana persepsi individu terhadap program tertentu merupakan landasan atau dasar utama untuk ikut terlibat dan berperan aktif dalam setiap kegiatan yang ada pada program tersebut. Notoatmodjo (2007) menjelaskan bahwa partisipasi terbentuk dengan didahului oleh faktor pendahulu seperti persepsi, pengetahuan, sikap, dan keyakinan. Artinya, ketika objek yang dipahami sesuai dengan kebutuhan atau keinginan, maka akan menimbulkan motivasi untuk bertindak. 
Berdasarkan hasil penelitian, sebagian besar persepsi ibu rumah tangga tentang bank sampah memiliki kriteria yang baik. Hal ini diikuti pula dengan rata-rata partisipasi pengelolaan Bank Sampah Gawe Rukun yang termasuk ke dalam kriteria tinggi, sehingga terjadi hubungan yang linier antara persepsi dengan partisipasi. Hal ini sesuai dengan hasil penelitian Ayunita (2012) yang menunjukkan bahwa apabila tingkat persepsi pada masyarakat dinaikkan, maka tingkat partisipasi juga akan meningkat.

Rata-rata persepsi tentang bank sampah yang tergolong baik atau positif, menunjukkan bahwa ibu rumah tangga RW 01 Kelurahan Kunciran Indah memandang sistem bank sampah itu penting, mempunyai tujuan yang baik, dan memiliki manfaat. Hal ini didukung oleh Rakhmat (2012) yang menyatakan bahwa penyebab munculnya persepsi positif adalah karena adanya kepuasan individu terhadap objek yang menjadi sumber persepsinya serta adanya pengetahuan dan pengalaman individu terhadap objek yang dipersepsi.

Ibu rumah tangga mendapatkan informasi tentang bank sampah yang memiliki aspek pendidikan, lingkungan, dan sosial ekonomi melalui suatu proses seleksi. Proses seleksi tentang bank sampah didapatkan oleh ibu rumah tangga melalui penyuluhan, membaca brosur dan spanduk, atau melihat secara langsung. Proses seleksi dalam mendapatkan informasi tentang bank sampah lebih banyak didapatkan oleh ibu rumah tangga dari aspek sosial ekonomi. Hal ini didukung dari hasil wawancara dengan Ketua RW 01 yang menyatakan bahwa pemberian penyuluhan tentang manfaat dari bank sampah lebih mengedepankan tentang manfaat bank sampah yang dapat menambah penghasilan dengan cara menabung dan memanfaatkan sampah. Hal ini dilakukan dengan tujuan untuk membuat ibu rumah tangga menjadi tertarik terhadap bank sampah. Muntazah dan Indrawati (2015) menyatakan bahwa keuntungan yang didapat dari hasil menabung sampah dapat membuat ibu rumah tangga menjadi nasabah bank sampah.

Informasi yang didapatkan oleh ibu rumah tangga dari berbagai sumber akan menimbulkan interpretasi tentang bank sampah. Hasil penelitian menunjukkan bahwa rata-rata skor tertinggi interpretasi tentang bank sampah terdapat pada aspek lingkungan. Hal ini berarti bahwa pada umumnya ibu rumah tangga menganggap sistem bank sampah dapat mengatasi permasalahan sampah yang semakin meningkat. Tingginya rata-rata skor seleksi dalam bidang sosial ekonomi tidak menyebabkan tingginya pula interpretasi dalam bidang sosial ekonomi. Hal ini dikarenakan interpretasi ibu rumah tangga tentang bank sampah dipengaruhi oleh berbagai faktor, seperti pengetahuan, pengalaman, motivasi, kepribadian, dan harapan-harapan yang ingin dicapai (Sobur, 2010).

Rata-rata skor interpretasi tentang bank sampah yang tertinggi terdapat pada aspek lingkungan. Hal ini diikuti pula dengan tingginya rata-rata skor reaksi tentang bank sampah pada aspek lingkungan. Reaksi atau tanggapan merupakan penerjemahan interpretasi dalam bentuk tingkah laku (Sobur, 2010).

Berdasarkan hasil wawancara, didapatkan hasil bahwa seluruh ibu rumah tangga RW 01 Kelurahan Kunciran Indah menganggap keberadaan bank sampah dapat membuat masyarakat menjadi peduli terhadap kebersihan tempat tinggal. Hal ini berarti bahwa seluruh ibu rumah tangga memiliki motivasi untuk menciptakan lingkungan menjadi lebih bersih, rapi, dan nyaman.

Reaksi merupakan hasil dari persepsi yang menjadi salah satu penentu tingkat partisipasi, karena persepsi merupakan proses psikologis yang tidak terlepas dari diri masing-masing individu yang berfungsi membentuk sikap dan menentukan keputusan 
untuk bertindak (Zulfarina, 2003). Persepsi yang positif pada ibu rumah tangga tentang bank sampah, maka akan membuat ibu rumah tangga memandang perlu untuk ikut berpartisipasi pada sistem bank sampah atau terlibat dalam menyukseskan program dan kegiatan yang ada di bank sampah. Hal ini sesuai dengan pernyataan bahwa individu akan secara sadar berperanserta dalam suatu kegiatan bila merasakan adanya manfaat bagi dirinya, baik secara langsung maupun tidak langsung. Sebaliknya, individu tidak akan turut berperan serta apabila merasakan kegiatan yang akan dilakukan tersebut merugikan atau tidak memberikan manfaat apapun (Emby, et al., 2011).

Pengelolaan Bank Sampah Gawe Rukun yang meliputi aspek perencanaan, pelaksanaan, dan evaluasi sangat tergantung kepada partisipasi ibu rumah tangga di lingkungan tersebut. Hal ini dikarenakan sehebat apapun suatu sistem yang diciptakan oleh pemerintah untuk mengatasi permasalahan sampah yang semakin meningkat, akan menjadi sia-sia jika tidak mendapat dukungan dari ibu rumah tangga di lingkungan tersebut.

Partisipasi pengelolaan Bank Sampah Gawe Rukun meliputi aspek keterlibatan fisik, kontribusi, dan tanggung jawab. Berdasarkan hasil penelitian didapatkan rata-rata skor tertinggi terdapat pada keterlibatan fisik dalam pelaksanaan. Hal ini berarti bahwa ibu rumah tangga lebih memilih untuk terlibat secara langsung pada saat kegiatan pelaksanaan dibandingkan pada tahap perencanaan dan evaluasi.

Davis (1999) yang menyatakan bahwa syarat terjadinya partisipasi adalah adanya kemampuan, kemauan, dan kesempatan dari individu. Berdasarkan hasil wawancara, kurangnya partisipasi pada tahap perencanaan dan evaluasi dikarenakan kurangnya kesadaran dan kemauan dari ibu rumah tangga untuk ikut berdiskusi membahas penentuan serta keberlanjutan kegiatan yang akan dilaksanakan.

Ibu rumah tangga menganggap bahwa pada tahap perencanaan dan evaluasi merupakan kewajiban dari pengurus bank sampah saja. Hal ini berarti bahwa ibu rumah tangga tidak memiliki kemauan untuk ikut berpartisipasi pada perencanaan dan evaluasi. Dengan demikian, para ibu rumah tangga lebih memilih untuk menjalankan saja program dan kegiatan yang telah dibuat oleh pengurus. Hal ini sesuai dengan hasil penelitian yang menunjukkan bahwa partisipasi ibu rumah tangga yang menjadi pengurus dan nasabah lebih tinggi dibandingkan dengan partisipasi ibu rumah tangga yang hanya sebagai nasabah. Hal ini dikarenakan semua tahapan pengelolaan Bank Sampah Gawe Rukun melibatkan peran serta dari para pengurus.

Rata-rata skor terendah berdasarkan hasil penelitian terdapat pada tanggung jawab dalam evaluasi. Berdasarkan hasil wawancara, rendahnya tanggung jawab dari ibu rumah tangga disebabkan karena kurangnya komitmen untuk selalu mengikuti setiap kegiatan yang ada di Bank Sampah Gawe Rukun dan menaati peraturan yang ada. Komitmen merupakan penerimaan yang kuat pada individu terhadap tujuan kelompok, sehingga membuat individu taat kepada peraturan kelompok (Terry, 2005). Komitmen bukan hanya janji yang harus ditepati dan diwujudkan, tetapi di dalamnya juga terkandung kesungguhan dan tanggung jawab. Kesungguhan untuk melakukan apa yang sudah diputuskan dan tanggung jawab untuk menyelesaikan dengan baik. Selain itu, adanya rasa kurang memiliki dari ibu rumah tangga untuk membuat sistem bank sampah menjadi berkelanjutan, sehingga seringkali mengabaikan undangan dari para pengurus Bank Sampah Gawe Rukun untuk ikut dalam rapat mengenai keberlanjutan sistem bank sampah. Partisipasi akan tumbuh jika dalam diri setiap anggota tumbuh rasa memiliki terhadap suatu program (Aini dan Setiawan, 2006). 
Persepsi ibu rumah tangga tentang bank sampah dengan partisipasi pengelolaan Bank Sampah Gawe Rukun harus ditingkatkan. Mikkelsen (2003) menyatakan bahwa keharusan berpartisipasi bertolak dari arah bahwa lingkungan hidup adalah milik bersama yang pemeliharaannya harus dilaksanakan oleh pemerintah, pelaku usaha, dan masyarakat. Hal ini berarti bahwa sistem bank sampah membutuhkan kerja sama dari pemerintah setempat dan ibu rumah tangga, sehingga sistem bank sampah dapat terus tumbuh dan berkembang.

Upaya yang dapat dilakukan untuk meningkatkan partisipasi ibu rumah tangga dalam pengelolaan bank sampah adalah dengan mengadakan penyuluhan dan pelatihan secara rutin kepada ibu rumah tangga. Penyuluhan adalah suatu proses pemberian pengetahuan dan keterampilan kepada masyarakat, sehingga terjadi suatu perubahan perilaku yang dapat meningkatkan kesejahteraan masyarakat. Penyuluhan memiliki tujuan untuk menumbuhkembangkan partisipasi masyarakat dalam pembangunan (Mardikanto, 2010).

Penyuluhan sangat penting artinya bagi ibu rumah tangga sebagai sarana sosialisasi dalam pemberian informasi. Mardijono (2008) mengungkapkan bahwa peran pemerintah tidak hanya berpengaruh terhadap persepsi masyarakat dalam menjabarkan arti pentingnya pengelolaan, tetapi peran pemerintah juga mampu mendorong sikap masyarakat dalam berpartisipasi aktif dalam pengelolaan.

Pengulangan pemberian penyuluhan dan pelatihan akan membuat stimulus yang awalnya tidak masuk dalam perhatian, maka akhirnya akan mendapatkan perhatian (Sobur, 2010). Partisipasi merupakan respon dari adanya stimulus yang didapatkan individu dari lingkungan. Berdasarkan hasil wawancara, belum banyak ibu rumah tangga yang diikutsertakan dalam kegiatan penyuluhan dan pelatihan terkait pengelolaan bank sampah yang diberikan dari pemerintah pusat. Ibu rumah tangga yang diikutsertakan dalam kegiatan penyuluhan dan pelatihan terkait pengelolaan bank sampah hanya sebatas pada ibu rumah tangga yang tergabung ke dalam organisasi tertentu saja, sedangkan ibu rumah tangga umum lainnya tidak diikutsertakan.

Mikkelsen (2003) menyatakan bahwa untuk meningkatkan partisipasi dalam keanggotaan, anggota perlu dilibatkan pada tahap perencanaan dan pengambilan keputusan. Pengambilan keputusan dalam pengelolaan Bank Sampah Gawe Rukun, antara lain saat penentuan harga beli sampah yang ditabung, penjadwalan untuk penimbangan sampah, pembentukan pengurus, serta perbaikan terhadap kegiatan dan program yang telah dijalankan. Peran serta masyarakat dalam pengambilan keputusan akan memberikan informasi yang berharga bagi pengambil keputusan dan mereduksi kemungkinan adanya konflik yang akan terjadi (Tjokroamidjojo, 1996)

Berdasarkan perhitungan koefisien determinasi, kontribusi persepsi ibu rumah tangga tentang bank sampah terhadap partisipasi pengelolaan Bank Sampah Gawe Rukun sebesar 56,28 \% dan 43,72\% berasal dari faktor lain. Faktor lain yang berkontribusi terhadap partisipasi dalam pengelolaan Bank Sampah Gawe Rukun antara lain adalah kesempatan, kemauan, dan lingkungan sosial. Soekanto (2009) menyatakan bahwa faktor lingkungan sosial adalah faktor yang ada di dalam struktur masyarakat yang terdiri dari kelembagaan sosial dan kepemimpinan.

\section{KESIMPULAN}

Berdasarkan hasil penelitian dapat disimpulkan bahwa terdapat hubungan positif antara persepsi ibu rumah tangga tentang bank sampah dengan partisipasi pengelolaan Bank Sampah Gawe Rukun, Kota Tangerang. Hal ini berarti bahwa semakin baik 
persepsi ibu rumah tangga tentang bank sampah, maka semakin tinggi partisipasi pengelolaan Bank Sampah Gawe Rukun, Kota Tangerang. Besarnya hubungan antara persepsi dengan partisipasi dalam penelitian ini adalah 0,7502 yang dinterpretasikan memiliki hubungan yang kuat. Hal ini berarti bahwa persepsi ibu rumah tangga tentang bank sampah memberikan kontribusi sebesar 56,28 \% pada partisipasi pengelolaan Bank Sampah Gawe Rukun, Kota Tangerang.

\section{DAFTAR PUSTAKA}

Aini, A dan Setiawan AH. (2006). Analisis Faktor-faktor yang Mempengaruhi Partisipasi Anggota Koperasi Serba Usaha Unit Simpan Pinjam Karyawan Pemerintah Daerah Kota Semarang. Jurnal Dinamika Pembangunan 3 (2).

Ayunita, D NND. (2012). Analisis Persepsi dan Partisipasi Masyarakat Pesisir pada Pengelolaan KKLD Ujungnegoro, Kabupaten Batang. SEPA 9 (1).

Badan Pusat Statistik Kota Tangerang. (2013). Kota Tangerang dalam Angka 2012 dan Angka Sementara 2013. Tangerang : BPS.

Chaesfa, Yulanda dan Nurmala. (2013). Persepsi Perempuan terhadap Lingkungan Hidup dan Partisipasinya dalam Pengelolaan Sampah Rumah Tangga. Jurnal Sosiologi Pedesaan.

Chalik, Alex Abdi. (2011). Formulasi Kebijakan Sistem Pengolahan Sampah Perkotaan Berkelanjutan Studi Kasus : DKI Jakarta. Jurnal Pemukiman 6, 18-30.

Davis, Keith. (1999). Human Behavior At Work. New York : Mc. Graw Hill Publishing Company.

Dinas Kebersihan dan Pertamanan Kota Tangerang. (2015). Data TPS Kota Tangerang 2015. Tangerang : DKP.

Emby, Z., Mohammadi, S.H., Norazizan, S., Ahmad, S., \& Soroush, A.. (2011). Relationship Between Citizen's Perception and Level Of Participation in Local Government. International Conference on Social Science and Humanity IPEDR 5, 431-435.

Ganet. (2013). Negara Asing Pelajari Pengelolaan Bank Sampah di Kecamatan Pinang. [Internet]. [diunduh 5 Januari 2016]. Tersedia pada : http://www.antarabanten.com/berita/21789/negara-asing-pelajari-pengelolaanbank-sampah-di-kecamatan-pinang

Mardijono. (2008). Persepsi dan Partisipasi Nelayan terhadap Pengelolaan Kawasan Konservasi Laut di Kota Batam. Tesis. Semarang : UNDIP

Mardikanto. (2010). Konsep Pemberdayaan Masyarakat. Surakarta : Tiga Serangkai.

Mikkelsen, B. (2003). Metode Penelitian Partisipatoris dan Upaya-Upaya Pemberdayaan. Jakarta : Erlangga.

Muntazah, Shofiyatul dan Indrawati Theresia. (2015). Pengelolaan Program Bank Sampah sebagai Upaya Pemberdayaan Masyarakat di Bank Sampah Bintang Mangrove, Surabaya. Jurnal Lingkungan Luar Sekolah.

Notoatmodjo. (2007). Pendidikan Kesehatan dan Ilmu Perilaku. Jakarta : Rineka Cipta.

Purwanti, F., Rahajeng, M.A., \& Hendrarto, B.. (2014). Pengetahuan, Persepsi, dan Partisipasi Masyarakat dalam Konservasi di Kawasan Cagar Alam Pulau Sempu Kabupaten Malang. Diponegoro Journal of Maquares 3 (4), 109-118.

Rakhmat, Jalaluddin. (2012). Psikologi Komunikasi. Bandung : PT Remaja Rosdakarya. Sobur, Alex. (2010). Psikologi Umum. Jakarta : Pustaka Setia.

Soekanto S. (2009). Sosiologi Suatu Pengantar. Jakarta : Rajawali Press. 
Terry, G.R.. (2005). Dasar-Dasar Manajemen. Jakarta : PT Bumi Aksara.

Tjokroamidjojo, Bintaro. (1996). Perencanaan Pembangunan. Jakarta : Gunung Agung. Tukidi. (2016, Februari 7 dan 8). Wawancara personal.

Utami, Eka. (2013). Buku Panduan Sistem Bank Sampah dan 10 Kisah Sukses. Jakarta : Yayasan Unilever Indonesia.

Wahyuni, Endah Tri. (2014). Optimalisasi Pengelolaan Sampah Melalui Partisipasi Masyarakat dan Kajian Extended Producer Responsibility (EPR) di Kabupaten Magetan. Jurnal Ekosains 6 (1), 8-23.

Zulfarina. (2003). Persepsi dan Partisipasi Petani terhadap Usaha Pertanian Konservasi. Tesis. Bogor : Institut Pertanian Bogor. 